\title{
Reproductive pattern of the South American endemic shrimp Artemesia longinaris (Decapoda: Penaeoidea), off São Paulo State, Brazil
}

\author{
A.L. Castilho ${ }^{1,2}$, R.C. Costa ${ }^{1,3}$, A. Fransozo ${ }^{1}$ \& E.E. Boschi ${ }^{4}$ \\ NEBECC (Group of Studies on Crustacean Biology, Ecology and Culture) \\ 2 Departamento de Zoologia, Instituto de Biociências, Universidade Estadual Paulista, UNESP, 18618-000 Botucatu, \\ SP, Brazil; castilho@ibb.unesp.br; fransozo@ibb.unesp.br \\ 3 Departamento de Biologia, Faculdade de Ciências, Universidade Estadual Paulista, UNESP, 81531-980, Bauru, SP, \\ Brazil; rccosta@fc.unesp.br \\ 4 Instituto Nacional de Investigación y Desarrollo Pesquero (INIDEP), Casilla de Correo 175, 7600 Mar del Plata, \\ Argentina; eboschi@inidep.edu.ar
}

\author{
Received 07-X-2005. C Corrected 18-IV-2006. Accepted 16-III-2007.
}

\begin{abstract}
Sexual maturity, temporal reproductive pattern, and recruitment of juveniles were examined for the penaeoid shrimp Artemesia longinaris sampled for five and a half years in a tropical locality off the coast of São Paulo (23 S), Brazil. Monthly samples were taken from January 1998 to June 2003 at depths between 5 and 45 $\mathrm{m}$. Ovarian maturity was used to examine breeding in adult females. Recruitment was defined as the percentage of juveniles of the total number of individuals in each month and season. A total of 10288 females and 5551 males were collected. Estimated sizes (carapace length) at the onset of sexual maturity were $11.0 \mathrm{~mm}$ and 13.4 $\mathrm{mm}$ for males and females, respectively. Over the five and a half years, females with ripe gonads were found in every season, with the highest percentages in summer (January-March). Juvenile shrimps occurred year-round. These results suggest a continuous reproduction of A. longinaris with temperature acting as an environmental stimulus for the duration of the ovary development cycle. These data and the hypothesis of the intrusion of the South Atlantic Central Water mass, which lowered water temperature and raised plankton production, suggest that the end of spring and the beginning of summer were the principal reproductive months. The classical paradigm of continuous reproduction at lower latitudes, with increased seasonality of breeding period at higher latitudes seems to apply to this species. Rev. Biol. Trop. 55 (Suppl. 1): 39-48. Epub 2007 June, 29.
\end{abstract}

Key words: Penaeidae, Artemesia longinaris, reproduction, reproductive pattern, recruitment, sexual maturity.

An accurate description of the spawning stock and its reproductive dynamics are central for the understanding the recruitment processes and the development of spawning stock/recruitment relationships in penaeid species (Crocos and van der Velde 1995). Spawning season for penaeid shrimps have been determined in previous studies by changes in the percentage of ripe females in the catch (O'Connor 1979, Crocos and Kerr 1983, García 1985, Crocos 1987, Bauer and Vega 1992, Bauer and Lin 1994, Crocos and Coman 1997, Minagawa et al. 2000, Crocos et al. 2001, Costa and Fransozo 2004).
Shrimp fisheries in southeastern Brazil target the most profitable species, such as the pink shrimp Farfantepenaeus brasiliensis (Latreille, 1817) and F. paulensis (PérezFarfante, 1967), the white shrimp Litopenaeus schmitti (Burkenroad, 1938), and the seabob shrimp Xiphopenaeus kroyeri (Heller, 1862). The increase of the fishing fleet and the decrease of landings of commonly exploited species have contributed to the expansion of the Artemesia longinaris Bate, 1888 fishery (D'Incao et al. 2002, Costa et al. 2005). The geographical distribution of this species is restricted to the western Atlantic, from Rio 


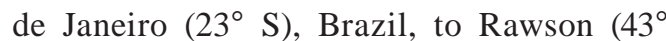
S), Argentina. This shrimp remains in the marine environment throughout its life cycle (Boschi 1969).

One of the main objectives concerning the study of the reproductive ecology of benthic invertebrates is to test latitudinal trends in the timing of reproductive activity and recruitment of juveniles. This approach can be used to test the effect of a given environmental stimulus (proximal factors) and to predict selective pressure (ultimate factors) accounting for a particular seasonal pattern of spawning and recruitment of juveniles. This methodology may also provide a basis to predict possible changes resulting from natural or anthropogenic disturbances (Bauer and Vega 1992).

In organisms with a short life cycle that are subjected to high fishing pressure, biological processes (environmental factors and food resources) that have occurred in one year define the stock's abundance in that same year. Interannual variability of temperature can cause changes in the reproductive pattern of a species in the same zone (Leal-Gaxiola et al. 2001).

São Paulo State is located between $23^{\circ} 20^{\prime}$ $\mathrm{S}$ and $25^{\circ} 15^{\prime}$ S latitude, and has a subtropicaltropical climate. There are only a few accounts of the reproduction of dendrobranchiate shrimps in this region. Almost all the published information regards populations of the species X. kroyeri (Rodrigues et al. 1993, Nakagaki and Negreiros-Fransozo 1998, Fransozo et al. 2000, Castro et al. 2005) and Rimapenaeus constrictus (Stimpson, 1874) (Costa and Fransozo 2004). Little is known about the reproductive periodicity of $A$. longinaris off the Brazilian coast. Fransozo et al. (2004), Castilho (2004), and Costa et al. (2005) studied aspects of its spatial and temporal distribution. Studies have been conducted in Argentinean waters, where this species is important not only for commercial fisheries, but also as a major component of the marine food web (Boschi 1969, Boschi and Scelzo 1977, Gavio and Boschi 2004).
The objective of this study was to determine the size at morphological and physiological sexual maturity of $A$. longinaris, to analyze the interannual and seasonal variations in spawning intensity and recruitment of juveniles during five and a half years off the coast of São Paulo, and to determine the relationship between its breeding season and the seabottom water temperature.

\section{MATERIALS AND METHODS}

Shrimps were collected monthly from January 1998 to June 2003 along the northern coast of São Paulo in the Ubatuba (23⒊'S,

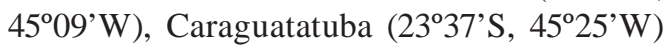

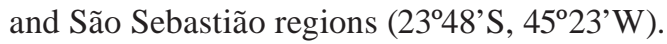
In each month, fourteen 2-km transects were trawled for $30 \mathrm{~min}$, at depths between 5 and 45 $\mathrm{m}$. A shrimp boat equipped with two doublerig nets (mesh size $20 \mathrm{~mm}$; cod end $15 \mathrm{~mm}$ ) was used for trawling.

On each transect, salinity and temperature (bottom and surface water), depth, organic matter content, and grain size of sediments were monitored. Detailed descriptions of the samplingmethodsandanalysis of environmental factors for the period are available elsewhere (Costa et al. 2004, 2005). Because this species inhabits the bottom, we used only the bottom temperature measurements for analysis.

All captured individuals were sexed and measured (to nearest $0.1 \mathrm{~mm}$ ). Carapace length (CL) was chosen as the size dimension, corresponding to the distance from the orbital angle to the posterior margin of the carapace. Size-frequency distributions were constructed separately to estimate the seasonality for males and females using 1.0-mm CL size intervals.

The relative frequency (\%) of adults in each size class was plotted, and the logistic function $y=\frac{1}{1+e^{r\left(C L-C L_{50}\right)}}$ was fitted to the data. $\mathrm{CL}_{50 \%}$ corresponds to the size at which $50 \%$ of the individuals are considered mature/ adults, and $r$ is the slope of the curve. Fitting was done by the least-squares method (Aguillar et al.1995, Vazzoler 1996), requiring 
a size-range overlap of adults and youngs of at least two size classes. The shrimps were therefore arranged in $1.0-\mathrm{mm}$ size intervals.

The reproductive condition of females was determined by macroscopic observation of the degree of ovarian development (color and volume occupied by the gonads) according to Castilho (2004) and Costa and Fransozo (2004). Ovaries categorized as immature varied from thin, transparent strands to thicker strands. Ovaries of adult females were much larger and thicker, and colored white (spent), light green (developing), or green to olive green (ripe).

Breeding intensity of the population was estimated as the percentage of mature females for each month and season. We chose the smallest size class which contained a female with a mature ovary as the lowest size limit for adult females as recommended by Bauer and Lin (1994). The reproductive status of males was assessed by examining the shape of the petasma, which is fused in adult individuals (Pérez-Farfante 1969, Boschi and Scelzo 1977).

Recruitment was defined as the percentage of juveniles of the total number of individuals in each month and season. Juvenile size classes were defined separately for males and females. Spearman's correlation coefficient was used to test the null hypothesis of no association between temperature and (a) the frequency of recruits and (b) the frequency of breeding females. In this analysis, monthly temperature and abundance values were plotted. Student's T-test was used to test size differences between male and females. The data were log-transformed prior to the analysis to test for normality (Zar 1999).

\section{RESULTS}

During this study, a total of 15839 shrimps (10 288 females and 5551 males) were captured. Female mean size was 14.4 $\pm 3.0 \mathrm{~mm}$ CL, ranging from 5.8 to $27.3 \mathrm{~mm}$. The mean size of the males was $12.1 \pm 3.0 \mathrm{~mm}$
CL, ranging from 5.5 to $21.9 \mathrm{~mm}$ CL. A twotailed Student's T-test indicated significant size differences between sexes $(\mathrm{p}<0.05)$.

Size at sexual maturity was estimated at $\mathrm{CL}_{50 \%}=11.0 \mathrm{~mm}$ for males and $\mathrm{CL}_{50 \%}=$ $13.4 \mathrm{~mm}$ for females. The largest female with immature gonads measured $10.9 \mathrm{~mm} \mathrm{CL}$; the smallest female bearing developed gonads was $9.9 \mathrm{~mm}$. The largest immature male measured $10.5 \mathrm{~mm}$; the smallest male with fused petasma was $8.9 \mathrm{~mm}$.

The reproductive condition of females and males is illustrated in size-frequency distributions from seasonal collections (Fig. 1). Annual cycles showed an increment of carapace size with modals of smaller sizes in summer and larger sizes in spring. For immature individuals, probable growth was estimated from summer until winter, when juveniles were few or absent. New recruitment was observed in spring. Larger specimens were obtained in the seasons with lower water temperatures, such as spring and winter 2001 (Fig. 1, 2).

Mature females occurred in every season, with higher percentages in summer, principally in 2000 and 2003. Peaks of females with spent ovaries were obtained in autumn (2001, 2002, 2003) and winter (1998, 1999, 2000) (Fig. 3). The abundance of mature females generally followed the same pattern as the bottom-water temperature (Fig. 4). In each year of the study, high percentages of females with mature gonads were recorded in months with temperatures near $22^{\circ} \mathrm{C}$. The bottom temperature varied between $17^{\circ} \mathrm{C}$ to $28^{\circ} \mathrm{C}$ and correlated significantly with the relative frequency of breeding females during January 1998 and June 2003 (Spearman, $\mathrm{p}<0.001$ ).

Temperature had a predominant influence in the months of warmer water $\left(>23^{\circ} \mathrm{C}\right)$, when lower percentages of mature females were recorded. The smallest percentage of females with mature ovaries was observed in 1998, with maximum water temperature of $27^{\circ} \mathrm{C}$ and a minimum of $22^{\circ} \mathrm{C}$. The temperature then decreased in November 1998, and during 

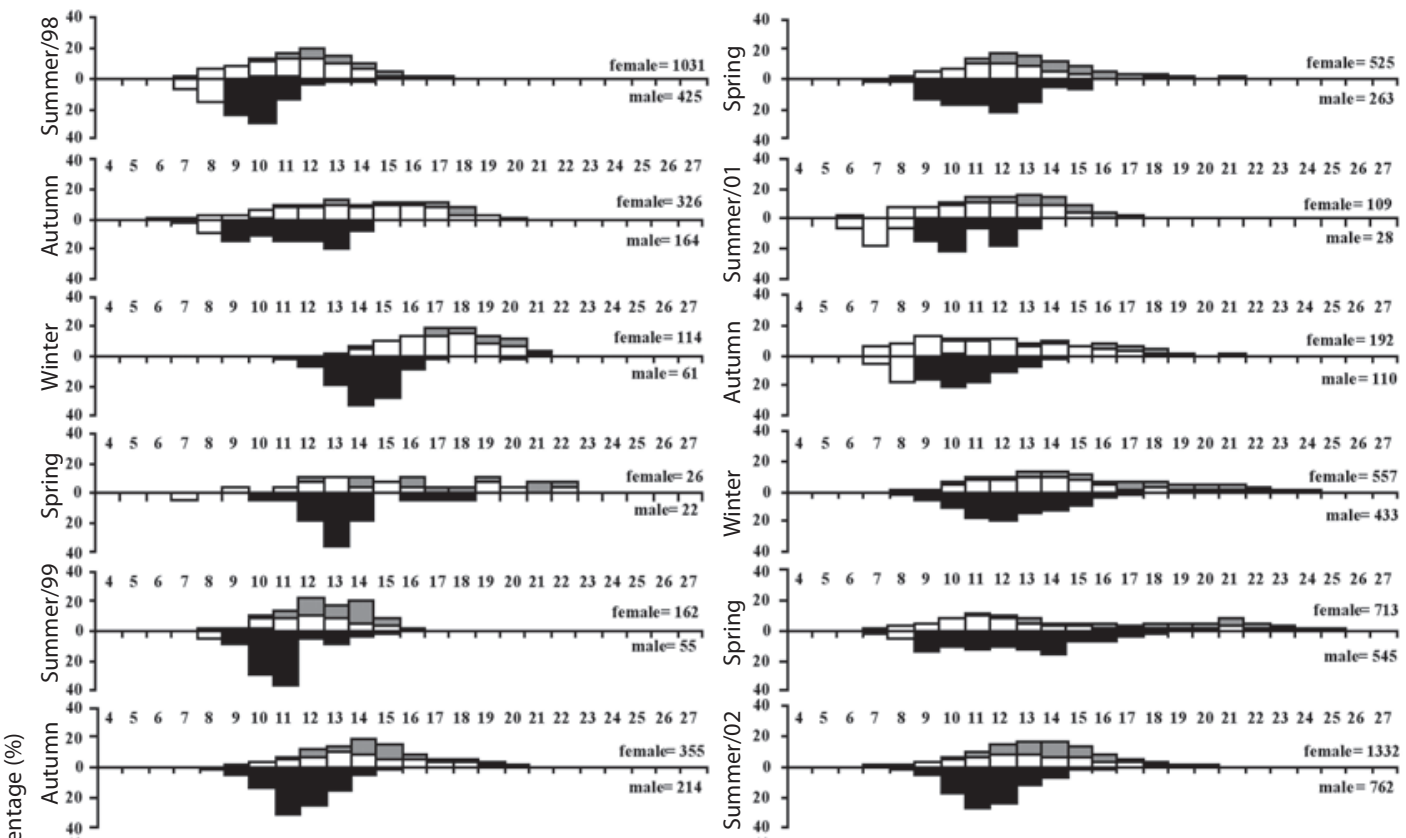

$\frac{\mathrm{d}}{\square}$
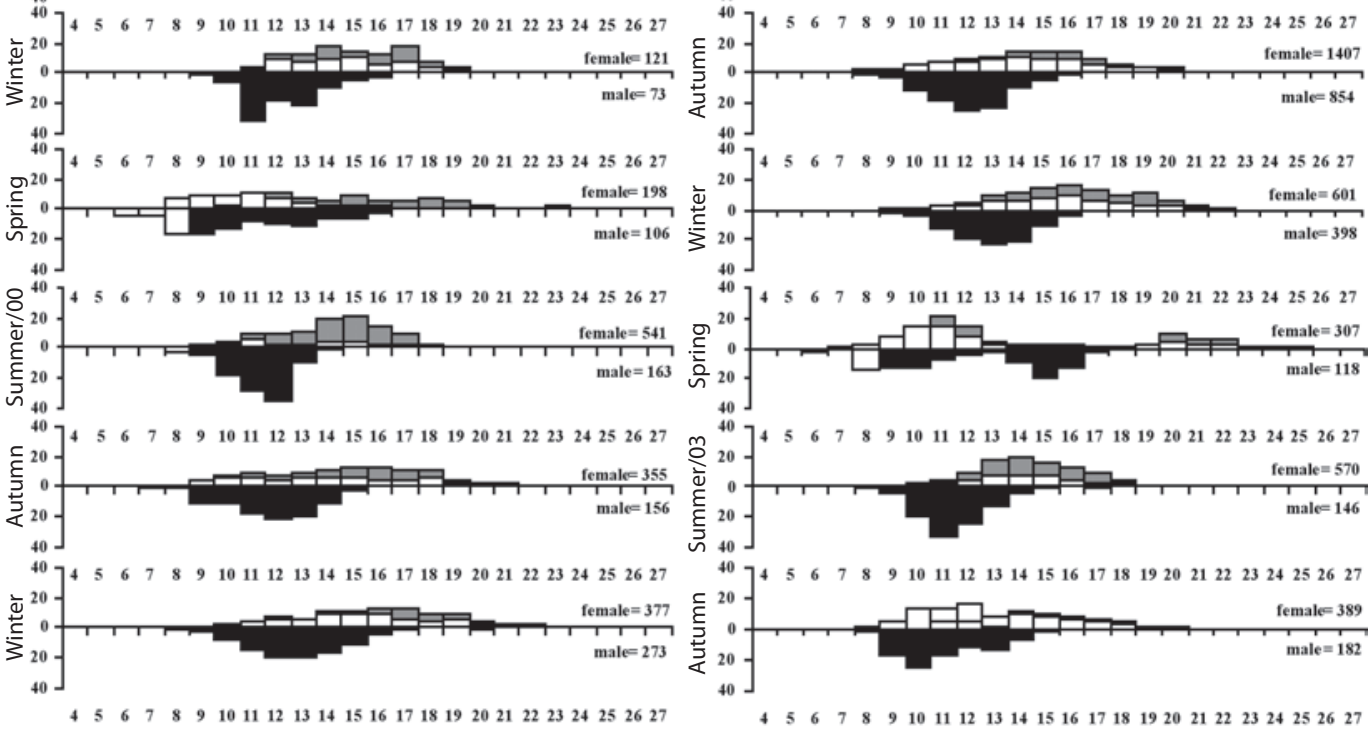

Carapace length $(\mathrm{mm})$

Fig. 1. Seasonality of size-frequency distributions of females and males of A. longinaris, with condition during the study period. Juveniles = white bar. Females: hatched bar = spent ovary; gray bar = mature ovary. Males, white bar = petasma unfused; black bar = petasma fused. 


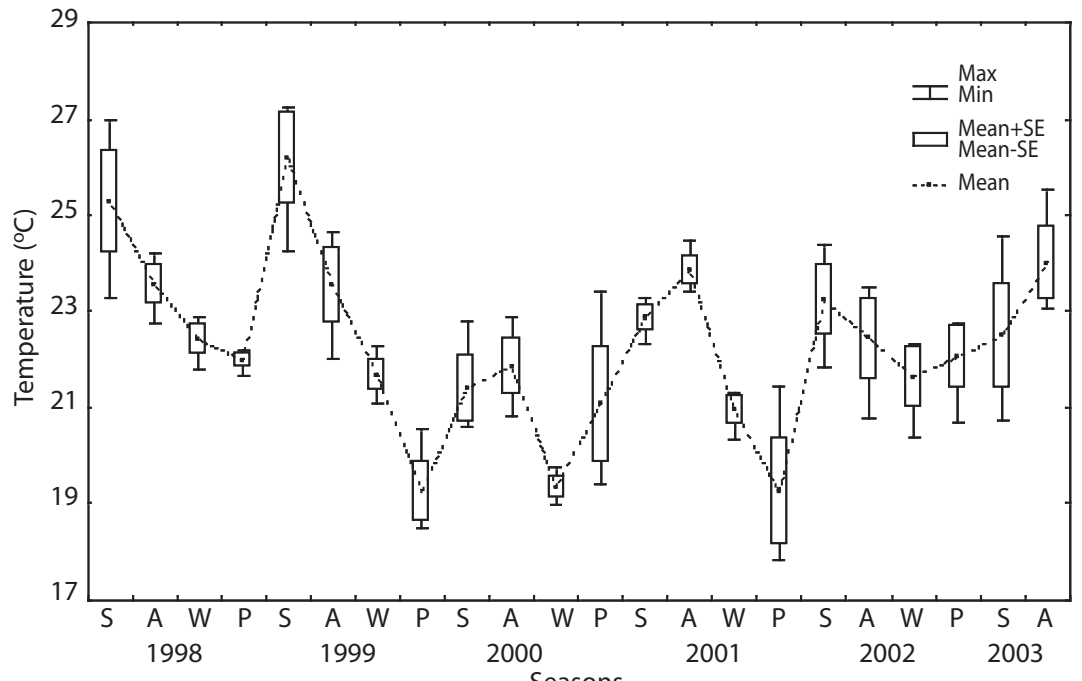

Fig. 2. Box-plots with mean, standard error (SE), and maximum (Max) and minimum (Min) temperature values for each season between January 1998 and June 2003. S: summer, A: autumn, W: winter, P: spring.

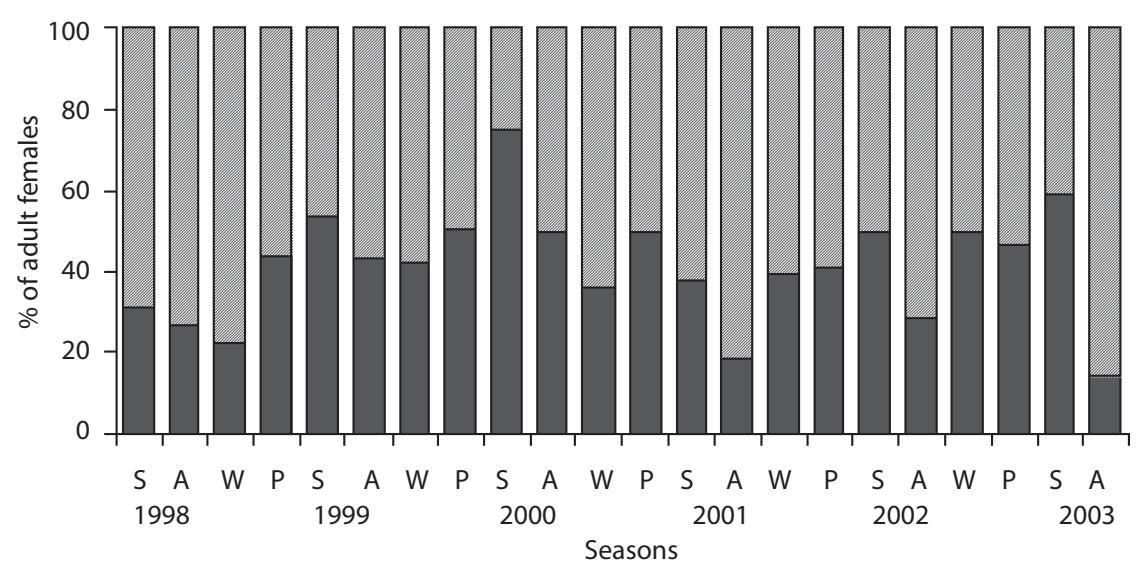

Fig. 3. Temporal pattern of A. longinaris: percentage of adult females with mature ovaries (gray bar) and adult females with spent ovaries (hatched bar) for each season over the five and a half-year study period. S: summer, A: autumn, W: winter, P: spring.

December 1998 and January 1999 (spring and summer) a peak of spawning females occurred. Elevated percentages of mature females were observed in January 2000 (summer, 22.8 ${ }^{\circ} \mathrm{C}$ ), and this proportion was maintained in the subsequent three months (temperature $=20.6$, 20.7 and $21.8^{\circ} \mathrm{C}$ ). The temperature increased in May $2000\left(22.9^{\circ} \mathrm{C}\right)$ when the number of mature females declined. In the other seasons, there were similar fluctuations in the percentages of spawning females and in bottom temperature (Fig. 2, 3, 4).

Recruitment estimates for $A$. longinaris based on the percentage of juvenile shrimps showed no evident seasonal patterns. The juveniles were found in low numbers during all months over the entire study period, except in November 2002 when immature individuals comprised $55 \%$ of the catch (Fig. 5). 
Bottom temperature $\left({ }^{\circ} \mathrm{C}\right)$

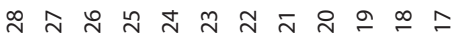
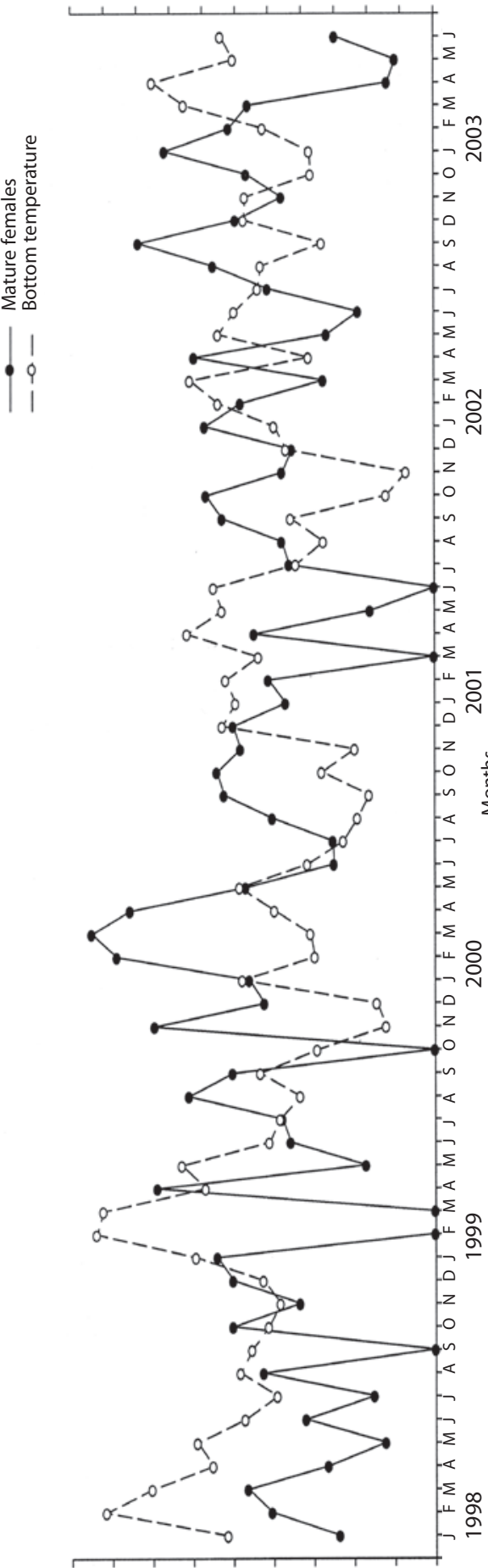

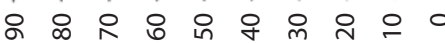

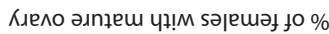

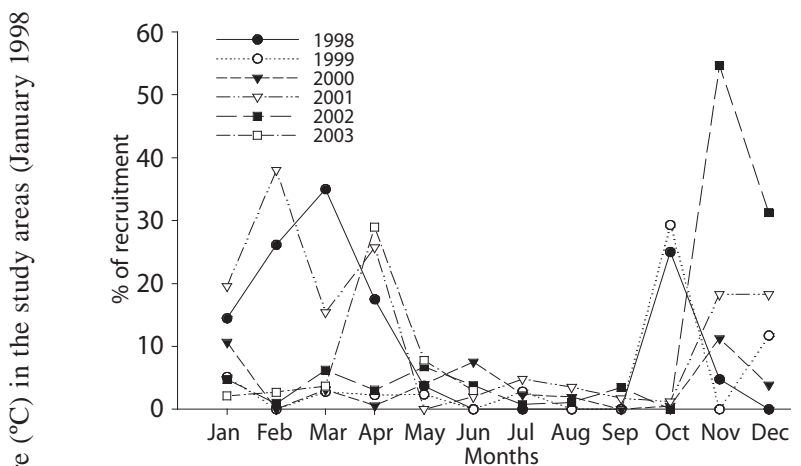

Fig. 5. Variation of the percentage of juveniles of $A$. longinaris in the study areas (January 1998 through December 1999).

\section{DISCUSSION}

Sexual dimorphism according to size occurred in A. longinaris: females grew larger than males, indicating differential growth rates between sexes. According to Boschi (1969), sex-related body-length differences between males and females are a general rule among penaeids. Gab-Alla et al. (1990) and Costa and Fransozo (2004) reported slower growth rates in males and suggested that reproductive processes are related to this difference.

In Argentina, Boschi (1997) found shrimps with different carapace lengths in each latitudinal region: for females $37 \mathrm{~mm}$ in Chubut $\left(43^{\circ} \mathrm{S}\right)$, and $29 \mathrm{~mm}$ in Mar del Plata $\left(37^{\circ} \mathrm{S}\right)$; for males $27 \mathrm{~mm}$ in Chubut and $24 \mathrm{~mm}$ in Mar del Plata. In the present study $\left(23^{\circ} \mathrm{S}\right)$, mean lengths were smaller: $27 \mathrm{~mm}$ for females and $21 \mathrm{~mm}$ for males. In Brazil the same latitudinal effect was observed in the sexual maturity of A. longinaris: in Rio Grande do Sul, females reached sexual maturity at 17 mm carapace length (Dumont 2003), $4.6 \mathrm{~mm}$ larger than the maturity size observed in the present study $\left(\mathrm{CL}_{50 \%}=13.4 \mathrm{~mm}\right)$. Bauer (1992) compared the longevity and size of females of Sicyonia spp. in tropical, subtropical and cool-temperate regions. Females of the larger species of Sicyonia (cool-temperate region) live at least two years, so that individual females have the opportunity to breed during a period 
of the year which might be most favorable for larval development and settlement. Thus, there is selection for seasonality in breeding patterns in these species. The small tropical sicyoniids live less than one year, and may settle and grow to sexual maturity at any time during the year. The same pattern may occur in A. longinaris when comparing growth and reproduction of populations in a tropical region (São Paulo state) and a more southern cool-temperate region (Mar del Plata).

The presence of juveniles and mature females throughout the year, as observed in January 1998 and June 2003, suggests that this species breeds continuously. However, there is evidence for more intense reproductive activity in summer than in spring. Otherwise, there were no seasonal trends in recruitment of juveniles. The seasonal variation in the frequency of females bearing mature ovaries was similar as reported for $R$. constrictus and $X$. kroyeri (Costa et al. 2004, Nakagaki and Negreiros-Fransozo 1998, respectively).

Vega-Pérez (1993) reported that during spring and summer the ocean chlorophyll content (phytoplankton production) was usually higher when the SACW (South Atlantic Central Water) intruded into the region during upwelling events. The phytoplankton production favored a subsequent production of herbivorous zooplankton resulting in the highest density of plankton organisms during summer (Pires-Vanin and Matsuura 1993). This variation coincides with our observations of the changes in frequencies of females with mature gonads, suggesting that food availability for larval protozoea (indicated by phytoplankton production) may be an important selective factor shaping the seasonal breeding pattern in this species.

In cool-temperate regions such as the Mar del Plata $\left(37^{\circ} \mathrm{S}\right)$, Christiansen and Scelzo (1971) observed highly seasonal breeding and spawning in A. longinaris with high percentages of mature females from October to January, whereas breeding apparently ceases during the rest of the year. For this species, the classical paradigm of continuous reproduction in the tropics and seasonal reproduction at higher latitudes, increasingly restricted in time with an increase in latitude, is supported by the results of the present study.

A. longinaris can be considered as a typical cold-temperate species. Boschi (1969), Ruffino and Castello (1992), Fransozo et al. (2004) and Costa et al. (2005) stated that the species occurs in a temperature range from 15 to $21^{\circ} \mathrm{C}$. Off southeastern Brazil, the upwelling current of the SACW is responsible, among other changes in bottomwater characteristics, for the cooling of coastal water during summer (Castro-Filho et al. 1987). The intrusion of the SACW was detected in this study during spring and summer, when mean water temperatures decreased (Negreiros-Fransozo et al. 1991, Mantelatto and Fransozo 1999, Bertini et al. 2001, Costa and Fransozo 2004). This may explain the lack of a significant correlation between the relative frequency of breeding females and bottom-water temperature. The shrimps A. longinaris and $P$. muelleri both migrate to the northern coast of São Paulo during the intrusions of cold SACW (Costa et al. 2004, 2005). We assume that the largest individuals captured in spring had migrated from other stocks located at higher latitudes.

Temperature was a specific environmental stimulus for the ovary development cycle, with a significant correlation between water temperature and the frequency of mature females. Petriella and Bridi (1992) observed the same relation in Mar del Plata, where high percentages of mature females of $A$. longinaris were present in months with higher temperatures. Christiansen and Scelzo (1971) and Petriella and Bridi (1992) demonstrated that spawning in A. longinaris in Mar del Plata was usually centered in the warmer months with sea-water temperatures higher than $20^{\circ} \mathrm{C}$. However, off a tropical coast such as São Paulo state, a smaller percentage of spawning females was found in the warmer months (March) when the mean bottom water temperature of $28^{\circ} \mathrm{C}$ is $8^{\circ} \mathrm{C}$ higher than at Mar del Plata. 
Insemination in species whose females have a closed thelycum occurs immediately after ecdysis (spent females), and the ovarian development cycle is closely linked with the molt cycle (Dall et al. 1990). The intrusion of the SACW was responsible for the decrease in the water temperature and the increase in plankton production, suggesting that the end of spring and beginning of summer were the principal reproductive months and, with the higher water temperatures at the end of summer, spawning occurred, followed by molting.

Recruitment was interpreted as episodic, because there was no apparent correlation between the percentages of mature females and immature individuals. A similar phenomenon has been reported for $R$. constrictus (Bauer and Lin 1994, Costa and Fransozo 2004). Probably, the complex and variable stockrecruitment relationships in penaeid shrimps depend on the food supply (primary and secondary productivity), predators and physical conditions of each region.

The present results may be used to develop a more appropriate fishery policy in the study region. Local fishing grounds should be more wisely exploited to reduce the ongoing decline of stocks. Trawl fishing may severely disturb the benthic environment in the Ubatuba region, and future studies of latitudinal variations in populations of $A$. longinaris could answer many questions about the degree of their reproductive plasticity. A molecular and morphological study could measure the differentiation of the populations in each region.

\section{ACKNOWLEDGMENTS}

The authors are grateful to the Fundação de Amparo à Pesquisa do Estado de São PauloFAPESP (\#94/4878-8, \#97/12108-6, \#97/12106-3, \#97/12107/0, and \#98/3134-6) and the Conselho Nacional de Desenvolvimento Científico e Tecnológico-CNPq for financial support during collections and analyses. We thank many colleagues from the NEBECC group who helped with sampling and laboratory analyses, to Janet Reid for her constructive comments on early drafts of the manuscript and great help with English language, to María Andrea Gavio for her constructive comments of the resumen and great help with Spanish language, and the Instituto Brasileiro do Meio Ambiente e dos Recursos Naturais Renováveis (IBAMA) for granting permission to collect the shrimps.

\section{RESUMEN}

El objetivo del presente trabajo fue el estudio de la madurez sexual, la reproducción temporal y el reclutamiento del camarón Artemesia longinaris, en el litoral del estado de São Paulo $\left(23^{\circ} \mathrm{S}\right)$, Brasil. El material fue recolectado mensualmente entre enero 1998 y junio 2003, hasta una profundidad de $45 \mathrm{~m}$. La periodicidad de la madurez gonadal fue verificada en las hembras adultas. El reclutamiento se definió como porcentaje de camarones inmaduros sobre el total de individuos en cada mes y estación. Se obtuvo un total de 10288 hembras y 5551 machos. Las tallas de la madurez gonadal estimadas fueron $11.0 \mathrm{~mm}$ (machos) y $13.4 \mathrm{~mm}$ (hembras). En los cinco años y medio del estudio, el verano (enero-marzo) siempre tuvo mayor porcentaje de hembras con gónadas maduras. En la mayoría de los meses, se recolectaron camarones inmaduros. Estos resultados sugieren que $A$. longinaris se reproduce en forma continua, y que la temperatura es el estimulo ambiental para la duración del desarrollo gonadal. Eso es evidente en los periodos con mayor desarrollo gonadal (primavera y verano) en aguas más frías y mejor oferta de alimento ofrecido por la penetración de las Aguas Centrales del Atlántico Sur y por el aumento en la productividad planctónica. Para este camarón se aplica el paradigma del efecto latitudinal en la reproducción de especies marinas, donde en regiones tropicales se observa una continuidad en el desarrollo gonadal y en las zonas templado-frías una estacionalidad reproductiva.

Palabras clave: Penaeidae, Artemesia longinaris, reproducción, patrones reproductivos, reclutamiento, madurez sexual.

\section{REFERENCES}

Aguillar A.T., Z.C. Malpica \& B.V. Urbina. 1995. Dinámica de Poblaciones de Peces. Libertad, Lima, Peru. 304 p.

Bauer, R.T. 1992. Testing generalizations about latitudinal variation in reproduction and recruitment patterns with sicyoniid and caridean shrimp species. Invertebr. Reprod. Dev. 22: 139-202. 
Bauer, R.T. \& L.W.R. Vega. 1992. Pattern of reproduction and recruitment in two sicyoniid shrimp species (Decapoda: Penaeoidea) from a tropical seagrass habitat. J. Exp. Mar. Biol. Ecol. 161: 223-240.

Bauer, R.T. \& J. Lin. 1994. Temporal patterns of reproduction and recruitment in populations of the penaeid shrimps Trachypenaeus similis (Smith) and T. constrictus (Stimpson) (Crustacea: Decapoda) from the north-central Gulf of Mexico. J. Exp. Mar. Biol. Ecol. 182: 205-222.

Bertini, G., A. Fransozo \& R.C. Costa. 2001. Ecological distribution of three species of Persephona (Brachyura: Leucosiidae) in the Ubatuba region, São Paulo, Brazil. Nauplius 9: 31-42.

Boschi, E.E. 1969. Estudio biológico pesquero del camarón Artemesia longinaris Bate de Mar del Plata. Bol. Inst. Nac. Invest. Desarr. Pesq. 18: 1-47.

Boschi, E.E. 1997. Las pesquerías de crustáceos decápodos en el litoral de la República Argentina. Invest. Mar. 25: $19-40$.

Boschi, E.E. \& M.A. Scelzo. 1977. Desarrollo larval y cultivo del camarón comercial de Argentina Artemesia longinaris. FAO Inf. Pesca. 159: 287-327.

Castilho, A.L. 2004. Dinâmica populacional do camarão Artemesia longinaris Bate, 1888 (Decapoda: Penaeidae) no litoral Norte do estado de São Paulo. Master Thesis, Universidade Estadual Paulista, Botucatu, Brazil. 80 p.

Castro, R.H., R.C. Costa, A. Fransozo \& F.L.M. Mantelatto. 2005. Population structure of seabob shrimp Xiphopenaeus kroyeri (Heller, 1862) (Crustacea: Penaeoidea) in the littoral of São Paulo, Brazil. Sci. Mar. 69: 105-112.

Castro-Filho, B.M., L.B. Miranda \& S.Y. Myao. 1987. Condições hidrográficas na plataforma continental ao largo de Ubatuba: variações sazonais e em média escala. Bol. Inst. Oceanogr. 35: 135-151.

Christiansen, H.E. \& M.A. Scelzo. 1971. Ciclo de maduración sexual y observaciones sobre la morfologia del aparato genital del camarón Artemesia longinaris Bate. Carpas 16 (5/D):1-22.

Costa, R.C. \& A. Fransozo. 2004. Reproductive biology of the shrimp Rimapenaeus constrictus (Decapoda: Penaeidae) in the Ubatuba region of Brazil. J. Crust. Biol. 24: 274-281.

Costa, R.C., A. Fransozo \& A.P. Pinheiro. 2004. Ecological distribution of the shrimp Pleoticus muelleri (Bate,
Gab-Alla, A.A.F.A., R.G. Hartnoll, A.F. Ghobashy \& S.Z. Mohammed. 1990. Biology of penaeid prawns in the Suez Canal Lakes. Mar. Biol. 107: 417-426.

García, S. 1985. Reproduction, stock assessment models and populations parameters in exploited penaeid shrimp populations, p. 139-158. In Rothlisberg, P.C., B.J. Hill \& D.J. Staples (eds). Second Australian National Prawn Seminar. Cleveland, Brisbane, Australia.

Gavio, M.A. \& E.E. Boschi. 2004. Biology of the shrimp Artemesia longinaris Bate, 1888 (Crustacea: Decapoda: Penaeidae) from Mar del Plata coast, Argentina. Nauplius 12: 83-94.

Leal-Gaxiola, A., J. López-Martínez, E.A. Chávez, S. Hernández-Vázquez \& F. Méndez-Tenorio. 2001. Interannual variability of reproductive period of the brown shrimp, Farfantepenaeus californiensis (Holmes, 1900) (Decapoda, Natantia). Crustaceana 74:839-851.

Mantelatto, F.L.M. \& A. Fransozo. 1999. Characterization of the physical and chemical parameters of Ubatuba Bay, northern coast of São Paulo State, Brazil. Rev. Bras. Biol. 59: 23-31.

Minagawa, M., S. Yasumoto, T. Ariyoshi, T. Umemoto \& T. Ueda. 2000. Interanual, seasonal, local and body size variations in reproduction of the prawn Penaeus (Marsupenaeus) japonicus (Crustacea: Decapoda: Penaeidae) in the Ariake Sea and Tachibana Bay, Japan. Mar. Biol. 136: 223-231.

Nakagaki, J.M. \& M.L. Negreiros-Fransozo. 1998. Population biology of Xiphopenaeus kroyeri (Heller, 1862) (Decapoda: Penaeidae) from Ubatuba bay, São Paulo, Brazil. J. Shellfish Res. 17: 931-935.

Negreiros-Fransozo, M.L., A. Fransozo, M.A.A. Pinheiro, F.L.M. Mantelatto \& S. Santos. 1991. Caracterização física e química da enseada da Fortaleza, Ubatuba, SP. Rev. Bras. Geogr. 21: 114-120.

O’Connor, C. 1979. Reproductive periodicity of a Penaeus esculentus population near Low Islets, Queensland, Australia. Aquaculture 16: 153-162.

Pérez Farfante, I. 1969. Western Atlantic shrimps of the genus Penaeus. Fish. Bull. 67: 461-590.

Petriella, A.M. \& R. J. Bridi. 1992. Variaciones estacionales del ciclo de muda y la maduración ovárica del camarón (Artemesia longinaris). Frente Marítimo 11:85-92.

Pires-Vanin, A.M.S. \& Y. Matsuura. 1993. Estrutura e função do ecossitema de plataforma continental da região de Ubatuba, Estado de São Paulo: uma introdução. Publção Esp. Inst. Oceanogr. 10: 1-8. 
Rodrigues, E.S., J.B. Pita, R. Graça-Lopes, J.A. Coelho \& A. Puzzi. 1993. Aspectos biológicos e pesqueiros do camarão sete-barbas (Xiphopenaeus kroyeri) capturados pela pesca artesanal no litoral do Estado de São Paulo. Bolm. Inst. Pes. 19: 67-81.

Ruffino, M.L. \& J.P. Castello. 1992. Dinámica poblacional del camarón (Artemesia longinaris) del sur de Brasil. Frente Marítimo 12 (A): 71-81.
Vazzoler, A.E.A.M. 1996. Biologia da Reprodução de Peixes Teleósteos: Teorias e Prática. Editora Eduem, Maringá, Brazil. 169p.

Vega-Pérez, L.A. 1993. Estudo do zooplâncton da região de Ubatuba, Estado de São Paulo. Pubção Esp. Inst. Oceanogr. 10: 65-84.

Zar, J.H. 1999. Biostatistical Analysis. Prentice Hall, Englewood Cliffs, New Jersey, USA. 663 p. 